\title{
Då Medft
}

\section{De? \\ Bürgerliden (sejeblud \\ in}

Einzeldarjtellungen.

I.

Strobal, Das Deut/die (Erbredt.

Bweite $\mathfrak{A}$ uflage.

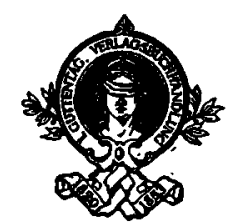

Berlin 1901.

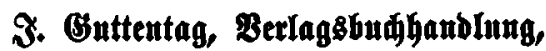

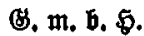




\section{Das deutfdee Errbredit}

$\mathfrak{a u j}$ Grumblage bez

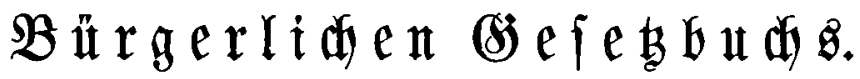

Bon

\section{Dr. Emil Sitrobal,}

ßrofeffor der Rerbte in Seipzig.

Zweite umgearbeitete unb vermehrte Muflage.

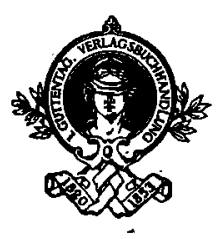

Berlin 1901.

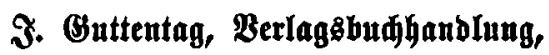

(s. m. b. $\$$. 



\title{
Dem Zndenfen
}

\author{
an

\section{Otto Mizller,} \\ weiland Senior der Leipziger Juriftenfałultät,
}

gewiomet. 
